\title{
Scandinavian-Saami Religious Connections in the History of Research*
}

\author{
BY HÅKAN RYDVING
}

In the study of Scandinavian religion a new phase began at the turn of the century, when hopes were placed on auxiliary sciences which were to supplement the philological analysis of the Old Icelandic texts. Especially archaeology, the study of sacred place-names and the newlydawned interest in Saami (Lappish) religion were sources of stimulation. Although the archaeological material was first and foremost - and still is - used to throw light upon different religio-historical theories, it also came to offer explanations for lacunæ in the literary sources (the recent development is discussed in several of the contributions in Words and objects 1986). Place-names had also been used earlier to illustrate the distribution of the worship of the gods, but more intensive use of them was inspired, above all, by the farreaching findings of Magnus Olsen. For half a century - and up to the critical re-valuations of the 1950's - place-names were to be the most important source category beside the written material (aspects of the history of research as well as the present state of scholarship are elucidated in other papers in the present volume). Saami religion supplemented Scandinavian sources as early as in an article by Johan Fritzner from 1877, but not until Axel Olrik presented and developed the ideas in some articles in 1905 and 1906 did they become generally known and used.

The religions of Scandinavians and Saamis have, for decades of scholarship, functioned as sources of analogies to explain elements in one another. For the study of Saami religion answers to questions about origins were sought in Scandinavian religion, while Saami religion has been seen by students of Scandinavian religion, as a preserver and a faithful witness of Scandinavian concepts and rites that had vanished in the times reflected in the literary sources. This view has now changed. In recent decades the tendency has been to use the loan-

\footnotetext{
* By courtesy of the editor of the present volume, this paper replaces 'Ortiamn som religionshistoriskt källmaterial' (Place-names as source material for the history of religions), since the latter is in the process of publication in Namn och Bygd (Uppsala).
} 
explanations more and more sparsely. Elements in Saami religion that were seen earlier as Scandinavian loans are now explained in a FinnoUgric context, whereas the few elements in Scandinavian religion that were thought of as loans from the Saamis are more often looked upon as inherited from a common origin, a North Eurasian cultural stratum. The search for analogies has, in any case, preoccupied the historian of religions in this field, too.

The purpose here is to provide a short and selective résumé of some aspects of a theme in the history of scholarship, a theme where "resemblances" have been found, compared, used as analogies, and - called into question: the comparative study of the religions of the Scandinavians and Saamis. ${ }^{1}$

\section{Loans}

The idea that Scandinavians had lent much to Saami religion occurs as early as in the sources. According to Hans Skanke, one of the Norwegian missionaries who collected material about Saami beliefs in the 1720 's, these were in a number of ways common with the religion of the Scandinavians, even though he asserts that Saami religion "in most superstitions" was something apart (Skanke 1945, 179). When the study of Scandinavian religion was intensified in the late 19th century and what was seen as resemblances were found in Saami religion, it was taken as self evident that the Saamis were the borrowers (cf. Fritzner $1877,154)$. Subsequently, nearly everything in Saami religion has been considered to have been taken over from the Scandinavians and explained for instance as "a rather clear reflected image of the worship they became acquainted with among their Nordic neighbours" (Olrik \& Ellekilde 1926-51, 105; cf. Olrik 1905a, 56).

The most important reason for this interest in Saami religion was the idea that, as it had been borrowed to a great extent from the Scandinavians, it would provide important evidence of Scandinavian customs. Very little, according to this view, would have been known about Scandinavian popular religion, if the Saamis had not preserved the ideas and customs that they had adopted (Olrik 1910, 2; Harva 1915a, 166; Harva 1915b, 13). The most extreme form of this interpretation was presented in a paper with the symptomatic title "Lappish

1 Cf. the general surveys of Scandinavian -- Saami cultural contacts in BradeanEbinger 1980, Fjellström 1970, Fjellström 1971, Gjessing 1965, Kasten 1983 and Nesheim 1979. 
contributions to Germanic mythology", a title which hints at the role it was believed Saami religion was going to play in the context of studies in Scandinavian religion. The author even considered that the Saami borrowings could be used as criteria by which to judge the religious ideas in the-Edda-literature, to separate what was common Scandinavian from what was Icelandic, and genuine heritage from Christian loans (Krohn 1906, 180). As late as 1942, the opinion was expressed that, in many cases, Scandinavian religious ideas were to be found in a more original form in the Saami (and Finnish) loans (Lid $1942,3)$. Saami parallels were thus used in support of various theories.

A much-debated question concerned the time of the loans. One opinion was that they represented the religion of the Nordic Bronze Age. Arguments for this theory were that three similar types of sacrificial gifts were known from both Bronze Age findings and the sources to Saami religion: rings interpreted as pictures of the sun, boats and hammers (Olrik 1905a, $39 \mathrm{ff}$.). More exactly, the loans were explained as adopted at a time "before our Viking Age, yes, that goes back to the Bronze Age, or at least to a time when the northernmost Nordic tribes, the nearest neighbours of the Lapps, still had rather much of the forms of worship of the Bronze Age in use" (Olrik 1905a, 55). Other ideas were that the loans did not belong to any distant "Urzeit" (Unwert 1911, 36), that they were very late, maybe from Scandinavians who had long been Catholic Christians (Reuterskiöld 1912, 104), or, as the pioneer Fritzner guardedly stated, that it is most difficult to decide if the loans were made during Christian or pre-Christian times (Fritzner 1877, 144).

It was mythological comparisons which attracted the greatest interest, and Saami and Scandinavian gods were identified with one another: Thor - Frey - Njord, the trinity of the old Icelandic incantation, with Horagállis ${ }^{2}$ - Vearalden olmmái - Bieggagállis, Odin with Rota etc. Saami material was used as a help to obtain knowledge about the Scandinavian gods.

The Saami god of thunder (Dierpmis, Horagállis etc.) was identified at an early stage with the Scandinavian Thor, although it was emphasized that the idea that the Saami god was a loan from the Scandinavians did not mean that a thunder god was earlier unknown among the Saamis (Fritzner 1877, $150 \mathrm{f}$.). Later it was nevertheless questioned whether the Saami thunder cult was indigenous at all (Krohn 1906, 165). Germanic elements in Saami conceptions of their

2 Saami words are, if not otherwise stated, given in SaaN. form 
thunder god(s) were, for example - in addition to one of the names of the god, Horagállis (Hora- < Thor-) - seen in his hammers, servant and wife (Harva 1915b, 73). The hammers of Horagallis were used as an argument for the use of hammers in the Scandinavian cult of Thor (Lid 1942, $127 \mathrm{ff}$.), and the heathen practice of making the sign of the hammer over the mead cup, usually explained as Christian influence, was, since the practice was also found among the Saamis, considered very old (Vries 1956-57, 2, 126). Since the Saamis knew a servant to the thunder-god, this figure must, according to Olrik, have been known by the Scandinavians, "not only as mythical figure, but also as the servant and envoy of the god in relation to the men that called upon him" (Olrik 1905b, 131). A figure interpreted as this "servant of the thunder god" on some Saami drums was identified with the onearmed Tyr (Bing 1922, 261) or Thjalfe (Reuterskiöld 1912, 109 with some hesitation). As late as in the new edition of his book about Loki, Georges Dumézil wrote about the "surviving of Scandinavian paganism in the religions of Lapps and Finns" and exemplified this with the information - found only in Snorri's Edda - that the mountain-ash (Sorbus aucuparia L.) was Thor's tree. The accuracy of this statement (and thereby of the Edda) was, according to him, confirmed by Finnish Rauni and Saami Ravdna as names of the wife of the thunder-god. The name is a loan from the old Scandinavian name of the mountain-ash, reynir $\left(<{ }^{*}\right.$ rauni-) (Dumézil 1986, 83; the comparison was first made in Krohn 1906, 167). Furthermore, Helge Ljungberg has used Saami analogies in support of the theory that there had been three IndoEuropean high gods, and, "that the Nordic thunder god was differentiated from the sky god (the sun god)" (Ljungberg 1947, 143, 52), and Jan de Vries has interpreted the myth of the whetstone in Thors head as derived from a cult action because of the Saami custom of knocking a nail with a whetstone into the head of the image of Horagállis, a practice viewed as a Scandinavian loan (Vries 1956-57, 2, 389).

Axel Olrik was the first to identify Vearalden olmmái with Frey (Olrik 1905a, 51), and the interpretation has been widely supported (Krohn 1906, 168 f.; Harva 1915b, 61; Lid 1942, 107; Vries 1956-57, 2, 177; Haavio 1969, 83). A smaller being, placed on some drums beside the figure interpreted as the fertility god has accordingly been compared to Skirnir, Frey's servant (Krohn 1906, 171 f.). One of the arguments for the identification of the two gods has been that the name of the Saami god was seen as an imitation of veraldar goð as a name of Frey. Martti Haavio has, however, provided a different interpretation. According to him, the Scandinavian veraldar 
god and the Saami vearalden olmmái are Christian designations, both

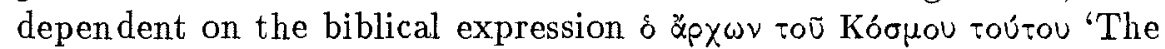
Prince of this world' (e.g. in John 12:31, 14:30, 16:11) used as a libellous and insulting name for any god (Haavio 1969, 58).

The identification of the wind god Bieggagállis or Bieggolmmái, with Njord (Olrik 1905a, 51 f.; Krohn 1906, 172 ff.) was criticized at an early date for being "much more insecure" then the combination of the Scandinavian and Saami thunder and fertility gods (Unwert 1911, 2), and it was pointed out that Bieggagállis could not have been one of the main gods of the Saamis, as Thomas von Westen, one of the source collectors (in Hammond 1787, 446), explicitly wrote that this god was not common (Reuterskiöld 1912, 110). Georges Dumézil has, however, argued in favour of Njord as "ruler of winds on land and on sea and protector of fishing-boats", claiming that these functions of $\mathrm{Njord}$ were displayed by "his Lappish transposé", Bieggagállis (Dumezil 1959, 122). ${ }^{3}$

The suggested identification of Odin with Bieggagállis (Olrik \& Ellekilde $1926-51,124$ ), has not played any significant role in the history of scholarship. Odin has instead been compared with Rota. The point of departure for this comparison was the Saami offering to Rota of a horse, an animal that the Saamis did not breed themselves. The rite was taken as a proof of the Scandinavian origin of the cult of Rota, and if the rite had a Scandinavian origin, the god, it was argued, had to be a loan, too. Wolf von Unwert, who identified Odin with Rota, argued that the reason why Odin's important features as god of war and the art of poetry were missing with Rota was because the Saamis had no need for these aspects, and he explained the different positions that the two gods took in their respective mythological systems by the argument that only individual cults and divinities, not the systematic mythology, had been transferred. Those sides of the character of the god that played no role in Saami culture had disappeared. Von Unwert maintained that Saami religion showed that a Germanic sacrificial practice was associated with Odin, that the horse was the sacrificial animal of Odin, and that Odin and the cult of the dead must have been closely connected with each other when the loan took place. The Saami Rota represented, according to him, the Odin of the final heathen period (Unwert 1911, $65 \mathrm{ff}$., $153 \mathrm{ff}$.). Other opinions were that Rota was a god that the Saamis had created themselves as an

${ }^{3}$ A different suggestion for a Saami parallel to Njord has been Cáhcolmmái [t $\left.\int a h t s-\right]$, the Saami god of water. Olrik \& Ellekilde 1926-51, 148. 
explanation for a horse sacrifice they had borrowed from the Scandinavians (Olrik 1905a, 53), or that he was neither one of the main Saami gods, nor to be identified with Odin (Reuterskiöld 1912, 98, cf. Dumézil 1959, 51).

The comparison of the Saami Áhkkás, or at least Sáráhkká, to the Norns (Fritzner 1877, 155; cf. Grundström 1956), was called into question (Reuterskiöld 1912, 90), but, if identified, the obvious differences between Áhkkás and the Norns were explained in two opposite ways. The Saami concepts represented, according to one opinion, an earlier phase of development, although Sáráhkka's emphasized position might have been caused by "later Nordic reinfluence" (Olrik \& Ellekilde $1926-51,140 \mathrm{f}$.). According to another interpretation, these goddesses more probably represented a degenerated form of late Scandinavian folk beliefs (Vries 1956-1957, 1, 272). The individual Áhkkás have also been interpreted in different ways. Máttaráhkká has for example been seen as a "product of speculation, that has its basis in Christian influence" (Reuterskiöld 1912, 97), Sáráhkká has been identified with Frigg (Agrell 1934, 70, 126) and Uksáhkká with the Scandinavian "dörrkärring" 'door woman' that lived under the threshold and blew out the candles that were carried through the door (Læstadius 1959, 37; Fritzner 1877, 156). The Saami Áhkkás were anyhow taken to prove that birth goddesses had existed among the Scandinavians, too (Vries 1956-57, 1, 272). ${ }^{4}$

Saami beliefs in various subterranean beings have also been interpreted as loans. The Saami beliefs in SaaS. saajve belonged, according to Olrik \& Ellekilde, to this category (Olrik \& Ellekilde 1926-51, 134), and the occurrence among the Saamis of these beings showed, according to Lid, that the belief must have been common among the Scandinavians in ancient times (Lid 1942, 144). Pentikäinen's analysis of the Nordic dead child traditions produced the conclusion that the corresponding Saami (SaaL. ähpár) tradition is a loan, where the name has been borrowed from Finland and the tradition from Scandinavia (Pentikäinen 1968, 328). A subterranean being among the Finnish Saamis (SaaN. cáhkkál, SaaSk. čeäkkli), with West and Middle European parallels, has further been explained as a loan which had

\footnotetext{
4 Other examples of identifications of deities are, for example, the idea that Rota was a counterpart to the Scandinavian Hel (Rosén 1920, $22 \mathrm{ff}$.), and that SaaS. Jijsienalmaj, the god of frost, was borrowed from the Scandinavians because the word SaaS. jijsie denotes 'hoar-frost on the grass', and the god therefore had to belong to a farming population. Harva $1915 \mathrm{~b}, 76$.
} 
come to the Saamis by Scandinavians or Finns (Gunda 1959, $114 \mathrm{f}$.). The whole of Saami mythology has even been interpreted as borrowed from the neighbouring peoples and connected with the saajve-belief (Reu terskiöld 1912, $71 \mathrm{ff}$.). ${ }^{5}$

With regard to rites and rituals, von Unwert enumerated the following loans from Scandinavians to Saamis: "sacrifices of domestic animals", "the use of farinaceous dishes and brass objects in cultic acts", "the placing of sacrificial gifts in small boats", "the specialized hallowed gifts for the separate deities", "the sacrifice of animals, buried alive in the earth", and "the characteristic attire of the sacrificer" (Unwert 1911, 1 f.). Others have furthermore mentioned the sun-cult (Krohn 1906, 163), the use of idols (Ljungberg 1947, 137), and the bear ceremony (Liljeholm 1926, 167).

The seidr has been seen as a giver of certain techniques to the Saami noaidevuohta ("shamanism"), and the development of the Saami drum into a "tool for oracle" has been interpreted as due to Scandinavian influence (Krohn 1906, 158). One idea has been that the drum pictures are not only Saami illustrations to mythological stories which had been taken over, but that the pictures themselves originate in an influence from the neighbours (Reuterskiöld 1928, 121; an attempt to interpret one of the drums with the help of the pictures on the Gallehus horns), that the pictures and also the divinatory uses of the drums had been adopted from the Scandinavians (O1rik \& Ellekilde 1926-51, 107), that the pictures of the three main gods on the Saami drums could be traced back to the pictures on the rock-carvings from the Bronze Age (Bing $1922,259)$, or, that the drums themselves were an inheritance from. the Nordic Bronze Age (Almgren 1926-27, 250). But according to another interpretation, the attributes of the gods on the drum pictures diverged from the rock-carvings of the Bronze Age, and were instead connected to "the more developed types of gods of the Iron Age" (Olrik \& Ellekilde 1926-51, 109).

If ideas about Scandinavian influence on Saami religion were common, there are only a few examples concerning influence in the opposite direction. Dag Strömbäck was certainly right when he wrote in 1935: "The question of the Nordic influence on Lappish religion stands for the present in the foreground. Indeed, one is tempted to say that it is so dominant, that it has entirely, or at least to a great extent, forced

5 Even the use of sacred stones, SaaN. sieiddit (sg. sieidi), has been explained as Scandinavian in origin, and the word sieidi has been compared to Scandinavian seiðr. Olrik \& Ellekilde 1926-51, 134. 
aside on the one hand the question of original features in the religion of the Lapps, and on the other the question of Lappish influence on Nordic religion" (Strömbäck 1935, 197 f.). Beside Strömbäck's supported theory that Saami shamanism had influenced Scandinavian seiðr (Strömbäck 1935, 205 f.; cf. e.g. Pettersson 1957, 169; Ström F. $1967,225)$, and the idea that the old Icelandic and Norwegian understanding of name-giving was a loan from the Saamis (Unwert 1913), one might mention the interpretation of the so called shield-poems as descriptions of drum pictures - Norwegian poets would have learned about and taken over Saami drums as epic instruments (Kabell 1980, 36). Régis Boyer has recently emphasized the role of the Saamis in shaping Scandinavian religion, with his opinion that the Saamis earlier lived right to the south of contemporary Norway and Sweden and were the indigenous stem onto which the northern Teutons were engrafted (Boyer 1986, 57 f.).

The loan-theory was for a long time the predominant explanation of resemblances between Saami and Scandinavian religion. The discussion first appeared in studies of Scandinavian religion. As Guttorm Gjessing has pointed out, as regards the study of Saami-Scandinavian contacts in general, the comparisons were often made between incommensurable phenomena, by comparing isolated elements regardless of structural context and abstracted forms of the cultures, instead of the regional variants that were actually encountered (Gjessing 1965, 172). Comparisons were furthermore made between the well-known (Scandinavian) and the lesser known (Saami) culture, and analogies were often sought without critical questions being asked about how the elements had been taken over, why certain elements were borrowed, and others not etc. Methodologically, the theory was treacherous, since similarities could always be explained as loans, and dissimilarities either as examples of beliefs and practices older than the literary Scandinavian sources, or, as more recent borrowed folk customs.

If the thesis that connections between the pre-Christian religions of Scandinavians and Saamis were mainly reflected in loans was previously completely dominant, this idea has, with a few exceptions, now disappeared from the study of Scandinavian religion. In the discussion of Saami religion, on the other hand, it still functions as something of a negative point of departure for much of the argumentation, since the antithesis which uses "inheritance" as the key to explain resemblances, has increasingly taken over the role of main theory. 


\section{Inheritance}

During the time when Saami religion was regarded as a conglomeration of Scandinavian elements, opinions about what was indigenous in Saami religion varied. At least shamanism, the adoration of trees and stones, the drums and certain sacrificial manners (Olrik 1905a, $56 \mathrm{f}$.), or, the adoration of the spirits of the departed, shamanism and the cult of the bear (Wiklund 1913, col. 171), or, the adoration of the departed and the cult of the bear (Krohn 1906, 156; Harva 1915b, 13) were recognized as more or less indigenous. Although more recent studies admit Scandinavian influences on Saami religion, they establish that this influence has been "greatly exaggerated" (e.g. Karsten 1955, 1).

One tendency - antithetical to the argument based on loans - has been to stress that the religions are "indigenous", i.e. not borrowed. An example is Pettersson's opinion that the Scandinavian and Saami religions were not related, but "specifically distinct" (Pettersson 1961, 132; cf. Pettersson 1987), or Johansen's harsh criticism of Olrik's reasonings, explaining Saami religion as something by itself, and claiming that Saami religion had "its pre-requisite inside the Saami culture alone" (Johansen 1983, 133).

Another tendency is to seek for analogies in a wider context than Fenno-Scandinavia. Scandinavian religion is then interpreted against an Indo-European, and Saami religion against a Uralic background. But, in this connection, it is more important to note that the field of vision can also be broadened to a North Eurasian or even circumpolar perspective, so that the cultures of the Scandinavians and the Saamis are regarded as more or less related.

A few examples from this debate will be sufficient to illustrate the tendencies:

The "Scandinavian traits" that Olrik and Krohn saw in the cult of Horagallis refer, according to this line of argument, "more to what is peripheral than to what is central in the cult of the thunder-god. In its essence this cult is unquestionable genuine Lapp" (Karsten 1955, 25). A difference between the Scandinavian and Saami thunder gods is that Horagállis is never ástvinr 'a dear friend' as Thor, but "regarded with awe", even though he is "man's helper", this latter explained as "most probable [...] an indigenous idea" (Pettersson 1961, 128). And it is furthermore "impossible to state conclusively if there are elements that are due to Scandinavian influences. The worship of the thunder-god is [...] common among different peoples of the world, and the character of this worship, its purpose and performance are often 
similar" (Pettersson 1961, 131). The idea that Dierpmis's functions as Supreme being and Thunder god among the western Saamis were divided between Vearalden olmmái and Horagállis because of Scandinavian influence (Hultkrantz 1962, 259) has been criticized. According to Mebius, the only thing we can state is that there "[...] in Saami religion incontrovertibly existed ideas about a sky-god, that, so far as can be judged, had a number of different names" (Mebius 1968, 153).

Beside the theory that Rota was to be identified with Odin, von Unwert strangely enough also presented - in a note - a totally different interpretation. According to this outline, Rota could be a genuine Saami god, and only the features that indubitably pointed to Odin were to have been taken over from the Scandinavian god (Unwert 1911, 157, n. 1). Arguments against a Scandinavian interpretation of Rota have been discussed (no animals were buried alive for Ruto, Ruto's horse on the drums doesn't have eight legs etc.) (Mebius 1968, $109 \mathrm{f}$.), as well as Uralic parallels, as for example the keremet-cult of the Mordvins and Maris (Cheremisses) (Harva 1915b, 28; Pettersson 1957, 162 f.; Pettersson 1985, 168), the Nenets (Yurak) $\eta \bar{a}$ and the Mansi (Vogul) xul'áatèr (Mebius 1968, 125; Pettersson 1985, 168). According to one opinion, a start should be made from the transference rite itself (Ränk 1981, 62; Ränk 1985, 170).

Regarding the Áhkkás, Harva observed at an early stage that not all the manners and customs connected with birth were borrowed from the Scandinavians (Harva 1915a, 168), and, according to Pettersson, the notion of the Áhkkás probably stemmed from what he calls the Finno-Ugric element in Saami religion (Pettersson 1957, 40). Ränk, on his part, has compared the Áhkkás with other Eurasian deities of birth, explained Máttaráhkká as secondary and stated that "the prerequisites to the coming into existence and further development of the Madder-akka complex are to be found in the Lapp religion itself" (Ränk 1955, 79). Also Bäckman has compared the Ahkkás with other North Eurasian deities, and according to her, Máttaráhkká represented "the Great-birth-mother" while Sáráhkká had "many common traits with those of the important Mother Fire" (Bäckman 1984, $37 \mathrm{f}$.). She thinks that the daughters were perhaps influenced by the Scandinavian Norns, but notes, that "the conception of the akkas in their roles as goddesses connected with birth can also be seen as an archaic element in the religious belief of the Saamis" (Bäckman 1984, 38).

K. B. Wiklund was the first to question the interpretatio scandinavica of Saami religion in his paper on the saajve-complex; the Pite and 
Lule Saamis have preserved an original Saami name, SaaL. ganij (pl. gadniha), for the type of beings who were mixed up with the "Toten im Berge" of the Scandinavians, and he hence posed the question whether the Saamis did not know subterranean beings of their own and of about the same kind as the Scandinavians. His criterion of "indigenous ideas" was whether the beings also were found among the Russian Saamis (Wiklund 1916, 46).

Åke Ohlmarks opposed the idea that the seidr was a loan from the Saamis (Ohlmarks 1939, 350). The same point was made later by $\AA$. V. Ström (Ström Å. V. 1975, 85, 259 f.), and Peter Buchholz has warned against interpreting every case of shamanism in the Old Icelandic sources as Saami influence (Buchholz 1968, 16). Åke Hultkrantz, on the other hand, has explained seidr and noaidevuohta as "[t]o a certain extent [...] two independent expressions of the northern shamanism" (Hultkrantz 1979, 55) and stated that "the Lappish influence on Nordic shamanism is probably not insignificant, though the latter also might have deeper roots in the Teutonic religion. On the other hand, the Lappish technique of divination seems to have had certain prototypes in the Nordic magic" (Hultkrantz 1962, 298). Interestingly enough, Eliade didn't consider seidr as shamanism in the strict sense. It belonged, according to him, instead to what he called 'minor magic' (Eliade 1972, 386 f.).

The significance of the North Eurasian perspectives has increased, but as early as 1926 Björn Collinder wrote concerning Scandinavian religion:

[...] it must to be taken as demonstrated that, in the heathen beliefs of Siberian and other sub-Arctic peoples as it has survived right on to our day, we possess a rich source of information about the religious ideas of our ancient forefathers [i.e. the Scandinavians] [...] Here we can discern in glimpses a religio-cultural connection which in olden times comprised large parts of our continent [...] As for the features of Old Teutonic heathen belief that have been found among the Lapps, it has hitherto been thought that the Norsemen in this respect have throughout played the role of lenders. To the extent that ideas and customs belonging to this category, as it transpires, are likewise found among the neighbours of the Lapps in the east, the above interpretation will lose a good deal of its probability (Collinder 1926, 230).

Recently, Lotte Motz has presented a new variant of the idea that the culture of the Saanis "reflects the customs and probably the ideas of the Mesolithic North" (Motz 1983, 365), and therefore could be used to supplement the literary sources to Germanic religion. Contrary to Olrik and the other scholars at the turn of the century, she does not 
restrict her parallels to Saami religion, but lists a number of resemblances between Germanic religion and the religions of various North Eurasian peoples, e.g. the Saamis, the Yakuts and the Chukchees, as regards cosmology, the spirit world, afterlife and some magical practices, and finds "[e]specially striking" parallels among the Chukchees (Motz 1983, 368). Motz explains these similarities by a common North Eurasian or circumpolar cultural heritage.

As for Saami religion, there are, according to Hultkrantz, two possibilities: either "that Lapp religious phenomena were derived from, or at least primarily related to, similar phenomena in the east; or that they constitute the archaic residue of a once coherent Eurasian (perhaps also circumpolar) hunting culture", being a "basic cultural pattern uniting all peoples in the extreme North" (Hultkrantz 1955, 85 f.). This North Eurasian perspective has been stressed in several recent studies of Saami religion and culture (cf. e.g. Mebius 1968, $80 \mathrm{ff}$.; Fjellström 1971, 546). Ränk can exemplify the argumentation:

I do not want to deny a certain Scandinavian influence on the Lapp culture and religion but I am convinced that the influence concerned more the external forms and terminology than basic religious conceptions. Furthermore [...] We are fully entitled to ask whether these religions are not originally related to one another and whether there exist in the North-Germanic religions ancient strata not absolutely without Arctic cultural influences (Ränk 1955, 10).

The brief and highly oversimplified account provided of a theme in the study of the religious history of Fenno-Scandinavia will serve to illustrate the use of analogies as explanations in the history of religions. The intensified methodological debate has created an awareness that knowledge about the history of scholarship is necessary to achieve a full understanding of all the hidden assumptions that influence the research process.

The scholars who searched for parallels to Scandinavian religion among the Saamis analyzed the Scandinavian (i.e. Old Icelandic) texts most scrupulously and with great philological skill, but used much less of their methodological insight when the Saami parallels were discussed, as generally only secondary literature and, in rare cases, one or two sources were used. They nevertheless lacked the essential linguistic knowledge of Saami as well as a basic familarity with Saami 
culture. The comparisons were morever, as mentioned above, made between isolated elements in the two cultures, elements taken out of their context, and the criteria for judging the "resemblances", were only discussed in exceptional cases.

When analogies to Saami or Scandinavian religion are sought among Mordvins, Chukchees and other peoples of the north, these analogies are also often collected from secondary literature and taken out of their cultural context without discussions of the criteria used for comparisons. The same criticism that was directed against the loan-theories is therefore, to a great extent, also valid here. The comparisons have been made between one religion that is well-known to scholars and one or more other religions much less familiar. The methodological problems are similar. There might be a risk that one type of less well-founded analogy replaces another.

The great interest in (Fenno-Scandinavian or North Eurasian) analogies is due to the fact that explanations based on questions of origins have almost entirely dominated studies of Fenno-Scandinavian religions (cf. Steffensen 1985, 105). The discussion has, to a great extent, fastened in a static view of both Scandinavian and Saami religion. It has, for example, been taken as more or less self-evident that the religions of pre-Christian Fenno-Scandinavia were rather uniform. This was, however, scarcely the case. We must reckon instead with great variation within the religious traditions of the different ethnic groups. There was never any uniform Saami (or Scandinavian) religion, but important regional variations, even though the condition of the sources produces the temptation to generalize on weak grounds. Thus, the written sources describing the southern Saami region are much more exhaustive than sources for other Saami areas, and the literary sources to Scandinavian religion describe almost exlusively Iceland and Norway, while very little is known about the religious ideas and practices of eastern and southern Scandinavia. Furthermore, various Christian missions penetrated parts of the area at different periods, and also influenced the religious life of those who were not converted, and the majority of the sources belong to the Christian period. This causes additional difficulties in separating the Christian from the pre-Christian.

The religious history of the region is thus very complex. The encounter of religions in pre-Christian Fenno-Scandinavia - involving Finns, Karelians and Russians as well as Scandinavians and Saamis - was no simple interchange of easily defined loans between well demarcated socio-cultural units, but a multiplicity of different dynamic 
processes. Not until more of these processes have been described on the micro-level, will it be possible to provide a tolerably correct synthesis of the religions. The whole spectrum of Scandinavian Saami religious connections would in fact be worth a new series of examinations.

\section{Bibliography}

\section{AbBreviations}

SaaL. Lule Saami

SaaN. North Saami

SaaS. South Saami

SaaSk. Skolt Saami

Agrell, S. 1934. Lapptrummor och runmagi. Lund.

Almgren, O. 1926-27. Hällristningar och kultbruk. (Kungl. Vitterhets Historie och Antikvitets Akademiens Handlingar 35.) Stockholm

Bäckman, L. 1984. The Akkas. Current progress in the methodology of the science of religion. Ed. by W. Tyloch. Warsaw.

Bing, J. 1922. Die Götter der südskandinavischen Felsenzeichnungen. Mannus 14. Leipzig.

Boyer, R. 1986. Le monde du double. Paris.

Bradean-Ebinger, N. 1980. Zur Frage der Nordisch-Lappischen sprachlichen und kulturellen Beziehungen. Uralica 5. Tokyo.

Buchholz, P. 1968. Schamanistische Züge in der altisländischen Überlieferung. Münster.

Collinder, B. 1926. Ett nytt uppslag i den fornnordiska religionsforskningen. Nordisk tidskrift för vetenskap, konst och industri utg. av Letterstedtska föreningen n.s. 2. Stockholm.

Dumézil, G. 1959. Les dieux des Germains. (Mythes et religion 38.) Paris.

- 1986. Loki. [Paris].

Eliade, M. 1972. Shamanism. (Bollingen Series 76.) Princeton.

Fjellström, P. 1970. Anpassning och egenart. Norrbotten. Luleå.

- 1971. Nordic and Eurasian elements in Lapp culture. Anthropos 66. Fribourg.

Fritzner, J. 1877. Lappernes Hedenskab og Troldomskunst sammenholdt med andre Folks, isaer Nordmaendenes Tro og Overtro. Historisk Tidskrift 4. Christiania.

Gjessing, G. 1965. Kontaktproblemet - konflikt og samarbeid. Norveg 12. Oslo

Grundström, H. 1956. Sarakkagröt - nornagröt - barselgröt - lystenbit. Arctica. (Studia Ethnographica Upsaliensia 11.) Uppsala.

Gunda, B. 1959. Ein altes europäisches Überbleibsel in der lappischen Mythologie. Ural-Altaische Jahrbücher 31. Wiesbaden. 
Haavio, M. 1969. Der oberste Gott der skandinavischen Lappen. Temenos 5. Turku.

Hammond, H. 1787. Den Nordiske Missions-Historie [.. .]. Kiøbenhavn.

[Harva], U. 1915a. De fornnordiska nornorna i lapparnas religion. [By] U. Holmberg. Nya Argus 18. Helsingfors.

- 1915b. Lappalaisten uskonto. [By] U. Holmberg. (Suomensuvun uskonnot 2.) Porvoo.

Hultkrantz, P. 1955. Swedish research on the religion and folklore of the Lapps. The Journal of the Royal Anthropological Institute of Great Britain and Ireland 85. London.

- 1962. Die Religion der Lappen. Die Religionen Nordeurasiens und der amerikanischen Arktis. Von I. Paulson \& $\AA$. Hultkrantz \& K. Jettmar. (Die Religionen der Menschheit 3.) Stuttgart.

- 1979. Lapp shamanism from a comparative point of view. Fenno-Ugrica Suecana 2. Uppsala.

Johansen, $\varnothing .1983$. Nor diske lån i før-kristen samisk religion? Viking 46. Oslo.

Kabell, Aa. 1980. Skalden und Schamanen. (FF Communications 227.) Helsinki.

Karsten, R. 1955. The religion of the Samek. Leiden.

Kasten, E. 1983. Kulturwandel bei den Samen. Berlin.

Krohn, K. 1906. Lappische Beiträge zur germanischen Mythologie. FinnischUgrische Forschungen 6. Helsinki.

Laestadius, L. L. 1959. Fragmenter i Lappska Mythologien. [Ed. by] H. Grundström Svenska Landsmål B, 61. Uppsala.

Lid, N. 1942. Innleiing. Gudar og gudedyrking. Religionshistorie. [Ed. by] N. Lid. (Nordisk kultur 26.) Stockholm.

Liljeholm, A. F. 1926. Nordiska fruktsamhetsriter i lapparnes björnfest. Folkminnen och folktankar 13. Lund.

Ljungberg, H. 1947. Tor. (Uppsala Universitets Arsskrift 1947, 9.) Uppsala.

Mebius, H. 1968, Värrō. (Skrifter utg. av Religionshistoriska institutionen i Uppsala. Hum. fak. 5.) Uppsala.

Motz, L. 1983. The northern heritage of Germanic religion. The Mankind Quarterly 23. Washington, DC.

Nesheim, A. 1979. Cultural contact of the Lapps with their neighbours. Fenno-Ugrica Suecana 2. Uppsala.

Ohlmarks, §. 1939. Studien zum Problem des Schamanismus. Lund.

Olrik, A. 1905a. Nordisk og lappisk gudsdyrkelse. Danske Studier. København.

- 1905b. Tordenguden og hans dreng. Danske Studier. København.

- 1910. Irminsul og Gudestøtter. Maal og Minne. Kristiania.

Olrik, A. \& Ellekilde, II. 1926-51. Nordens Gudeverden 1-2. København.

Pentikäinen, J. 1968. The Nordic dead-child tradition. (FF Communications 202.) Helsinki. 
Pettersson, O. 1957. Jabmek and Jabmeaimo. (Lunds universitets årsskrift N.F. 1, 52, 6.) Lund.

- 1961. Tirmes - Dierbmes - Horagalles - Thor. Knut Lundmark and man's march into space - a memorial volume. Göteborg.

- 1985. The god Ruto. Saami pre-Christian religion. Ed. by L. Bäckman \& $\AA$. Hultkrantz. (Stockholm Studies in Comparative Religion 25.) Stockholm.

- 1987. Old Nordic and Christian elements in Saami ideas about the realm of the dead. Saami religion. Ed. by T. Ahlbäck. (Scripta Instituti Donneriani Aboensis 12.) Stockholm.

Ränk, G. 1955. Lapp female deities of the Madder-Akka group. Studia Septentrionalia 6. Oslo.

- 1981. Der mystische Ruto in der samischen Mythologie. (Stockholm Studies in Comparative Religion 21.) Stockholm.

- 1985. The North-Eurasian background of the Ruto-cult. Saami preChristian religion. Ed, by L. Bäckman \& $\AA$. Iultkrantz. (Stockholm Studies in Comparative Religion 25.) Stockholm.

Reuterskiöld, E. 1912. De nordiska lapparnas religion. (Populära etnologiska skrifter 8.) Stockholm.

- 1928. Från guldhornen till lapptrumman. Festskrift til Rektor J. Qvigstad. (Tromsø museums skrifter 2.) Troms $\varnothing$.

Rosén, H. 1920. Om lapparnas dödsrikesföreställninger. Fataburen 1919. Stockholm.

Skanke, H. 1945. Epitomes Historiæ Missionis Lapponicæ 1, [Ed. by] O. Solberg. Nordnorske samlinger 5,2 . Oslo.

Steffensen, A. 1985. Samisk religion. Chaos 4. København.

Ström, ̊. V. 1975. Germanische Religion. Germanische und Baltische Religion. Von $\AA$. V. Ström \& II. Biezais. (Die Religionen der Menschheit 19, 1.) Stuttgart.

Ström, F. 1967. Nordisk hedendom. Göteborg.

Strömbäck, D. 1935. Sejd. (Nordiska texter och undersökningar utg. i Uppsala av Bengt Hesselman 5.) Stockholm.

Unwert, W. von 1911. Untersuchungen über Totenkult und Odinnverehrung bei Nordgermanen und Lappen [...] (Germanische Abhandlungen 37.)

- 1913. Namengebung und Wiedergeburtsglaube bei Nordgermanen und Lappen. Beiträge zur Sprach- und Völkerkunde. Halle.

Vries, J. de 1956-57. Altgermanische Religionsgeschichte 1-2. (Grundriss der germanischen Plilologie 12, 1-2.) Berlin.

Wiklund, K. B. 1913. Mytologi [lapsk]. Nordisk familjebok 19. Stockholm.

- 1916. Saivo. Le monde oriental 10. Uppsala.

Words and objects. 1986. Ed. by G. Steinsland. (Instituttet for sammenlignende kulturforskning, B, 71.) Oslo. 